\title{
Dinosaur tail sign on spinal MRI in a patient with postdural puncture headache
}

\author{
Keita Sakurai, ${ }_{1}^{1}$ Satoru Morimoto, ${ }^{2}$ Masashi Kameyama, ${ }^{1}$ Mitsuhito Mase ${ }^{3}$
}

'Department of Diagnostic Radiology, Tokyo Metropolitan Medical Center of Gerontology, Tokyo, Japan

${ }^{2}$ Department of Neurology, Tokyo-to Kenko Choju Iryo Center, Tokyo, Japan ${ }^{3}$ Department of Neurosurgery, Nagoya City University Graduate School of Medical Sciences, Nagoya, Japan

\section{Correspondence to Dr Keita Sakurai, ksak666@yahoo.co.jp}

Accepted 14 July 2017

\section{DESCRIPTION}

A 68-year-old man presented with cognitive impairment, urinary incontinence and short step gait. These symptoms, together with brain MRI finding, suggested idiopathic normal pressure hydrocephalus. After a spinal tap test to confirm the diagnosis, he suffered from postdural puncture headache. Despite an equivocal finding on spinal MR myelography (MRM), lumbosacral fat-suppressed T2-weighted image (FST2WI) clearly showed the characteristic 'Dinosaur tail sign' indicative of cerebrospinal fluid (CSF) leakage (figure 1). ${ }^{1}$ This pathognomonic sign disappeared on symptom improvement (figure 1).

Spinal MRM is a radiation-free technique with excellent high-contrast resolution, making it possible to detect epidural fluid collections. Considering its non-invasiveness and high sensitivity for fluid signals, this technique should be used as the first-line examination in diagnosing CSF leakage. ${ }^{23}$ However, it could be hard to detect subtle epidural CSF leakage on spinal MRM using a two-dimensional sequence. On the other hand, sagittal FST2WI can be a useful technique to evaluate the subtle interspinous arched hyperintensities indicative of subtle epidural CSF leakage.

This case emphasises the use of 'Dinosaur tail sign' on lumbosacral sagittal FST2WI to reflect subtle

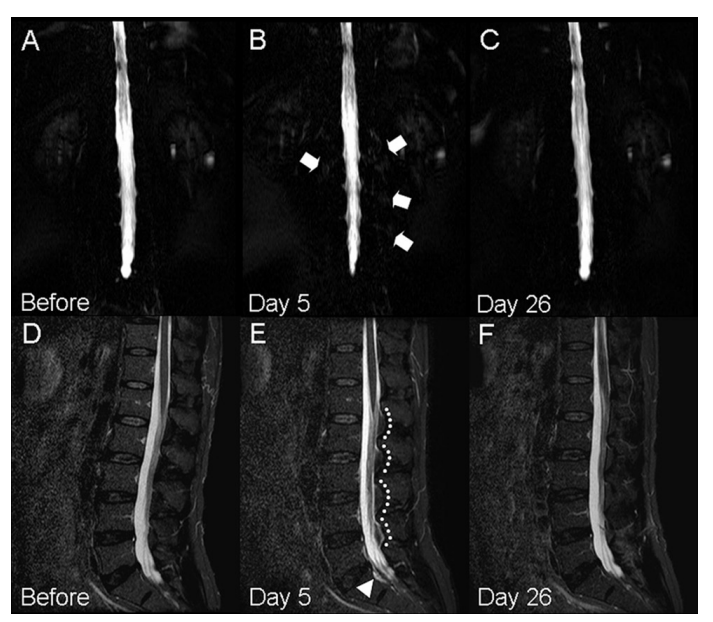

Figure 1 Serial MRM and FST2WI before (A, D) and after a dural puncture $(B, C, E, F)$. In contrast to subtle paraspinal hyperintensities on MRM (arrows, B), sagittal FST2WI shows characteristic dorsal epidural fat tissues demarcated by interspinous arched hyperintensities (dash lines, E) contributing to the 'Dinosaur tail sign' and slight epidural hyperintensity (arrowhead, E). Pathognomonic signal changes disappear on symptom improvement (F). FST2WI, fat-suppressed T2-weighted image; MRM, MR myelography.

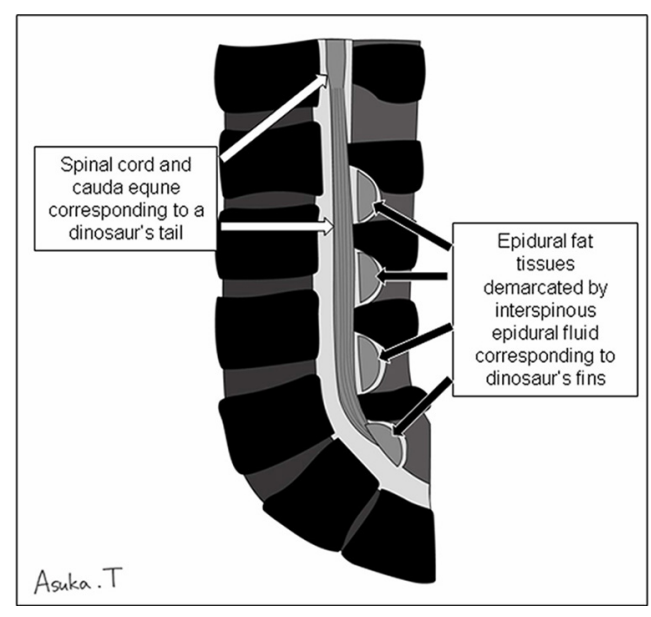

Figure 2 A schema of the 'Dinosaur tail sign'. This illustration represents that the combination of the spinal cord, cauda equine and dorsal epidural fat tissues resembles a dinosaur's tail and fins; therefore, this finding is termed as the 'Dinosaur tail sign'.

\section{Learning points}

- The 'Dinosaur tail sign' is a useful imaging finding indicative of subtle cerebrospinal fluid (CSF) leakage.

- In addition to spinal magnetic resonance myelography, evaluation of subtle interspinous arched hyperintensities on lumbosacral fat-suppressed T2-weighted image is mandatory for the accurate diagnosis of CSF leakage.

extravasated epidural fluid collection to enable the accurate diagnosis of CSF leakage (figure 2).

Contributors KS: case report concept, interpretation of data and critical revision of manuscript for intellectual content. SM: interpretation of clinical data. MK: interpretation of imaging data. MM: acquisition of data, collection and assembly of data, and case report supervision.

Competing interests None declared.

Patient consent Obtained.

Provenance and peer review Not commissioned; externally peer reviewed.

(c) BMJ Publishing Group Ltd (unless otherwise stated in the text of the article) 2017. All rights reserved. No commercial use is permitted unless otherwise expressly granted.

\section{REFERENCES}

1 Sakurai K, Kanoto M, Nakagawa M, et al. Dinosaur Tail Sign: a Useful Spinal MRI Finding Indicative of Cerebrospinal Fluid Leakage. Headache 2017;57:917-25. 


\section{Images in...}

2 Wang YF, Lirng JF, Fuh JL, et al. Heavily T2-weighted MR myelography vs CT myelography in spontaneous intracranial hypotension. Neurology 2009;73:1892-8.

3 Sakurai K, Matsukawa N, Okita K, et al. Lumbar puncture-related cerebrospinal fluid leakage on magnetic resonance myelography: is it a clinically significant finding? BMC Anesthesiol 2013;13:35.

Copyright 2017 BMJ Publishing Group. All rights reserved. For permission to reuse any of this content visit http://group.bmj.com/group/rights-licensing/permissions.

BMJ Case Report Fellows may re-use this article for personal use and teaching without any further permission.

Become a Fellow of BMJ Case Reports today and you can:

- Submit as many cases as you like

- Enjoy fast sympathetic peer review and rapid publication of accepted articles

- Access all the published articles

- Re-use any of the published material for personal use and teaching without further permission

For information on Institutional Fellowships contact consortiasales@bmjgroup.com

Visit casereports.bmj.com for more articles like this and to become a Fellow 